\title{
Petrographic and Geochemical Characteristics of the Metabasites of the SASCA Domain (Yonaké, Mani- Béréby and Dehié Sectors), South-West Côte d'Ivoire
}

\author{
Kouadio Fossou Jean-Luc Hervé, Enseignant-Chercheur \\ Houssou N'guessan Nestor, Enseignant-Chercheur \\ Allialy Marc Ephrem, Enseignant-Chercheur \\ Gnanzou Allou, Enseignant-Chercheur \\ Djro Sagbrou Chérubin, Enseignant-Chercheur
}

Laboratory of Geology, Mineral and Energy Resources (LGRME),

Faculty of Earth Science and Mineral Resources, Félix Houphouët Boigny

University, Abidjan, Côte d'Ivoire

Doi:10.19044/esj.2020.v16n21p247 URL:http://dx.doi.org/10.19044/esj.2020.v16n21p247

\begin{abstract}
The petrographic and geochemical study of six (6) metabasites located in the Archean-Paleoproterozoic transition domain (SASCA domain, South-West Côte d'Ivoire) identified dolerites and gabbros. The thin sections revealed two textures: the doleritic texture (dolerite) and the granoblastic texture (gabbro). The dolerites are composed of plagioclase wands, pyroxene and olivine. Gabbros have a composition of pyroxene (clinopyroxene), green hornblende, plagioclase, biotite and rare quartz. Geochemical analysis, especially the major elements, corroborated the gabbroic character of the metabasites. Trace elements and rare earths helped to constrain the origin of the metabasites by showing: (i) their belonging to a tholeiitic series, (ii) a mantle source contaminated by the continental crust, and (iii) their emplacement in the field of intraplate or volcanic arc basalts.
\end{abstract}

Keywords: Petrography, Geochemistry, Metabasite, SASCA Domain, Côte d'Ivoire

\section{Introduction}

The geological formations of south-west Côte d'Ivoire consist of several metamorphic units, and Eburnean plutonic rocks grouped into two domains (Papon, 1973): the Man domain and the SASCA domain (named after the Sassandra and Cavally rivers which limit this area). The domain of Man, where the Archean predominates (Figure 1), is characterised by its lithology and its particular structures. At the petrological level, grey gneisses 
are a typical Archean lithology, of which TTG orthogneiss suites are a common component that has been the focus of extensive research (Moorbath et al., 1972; Moorbath, 1975; Savanier et al., 2003; Martin et al., 2014, Koffi et al., 2020). Whereas in the SASCA domain, we observe lithologies mainly composed of metasediments (paragneiss, micaschists), grey gneiss (Kouamelan, 1996; Kouamelan et al., 2015; Kouadio, 2017), all intruded by granitoids as well as dolerite or metabasite dykes (Papon, 1973; Kouadio, 2017). Mafic dykes swarms may simultaneously provide information on the geodynamic setting, geochemical characteristics of their mantle source areas, age distribution and paleomagnetic-determined positions (paleolatitude and paleo-orientations) at the time of their formation (Ernst, 2014). There have been several such studies of West African (in both the southern and northern parts of the craton) and also of Amazonian dykes (Nomade et al., 2003; De Roever et al., 2003; El Bahat et al., 2013; Kouyaté et al., 2013; Youbi et al., 2013). Regional-scale mapping of mafic dykes based on airborne geophysical data is the first step in the interpretation of mafic dykes swarms as it aids in regional correlation of outcrop scale observations. Mafic dykes are typically rich in magnetite giving them a high susceptibility and remanence. Most of the time they cross-cut the stratigraphy, they typically show up clearly in magnetic anomaly maps. The new map of magnetic dykes swarms for the West African Craton (WAC) based on aeromagnetic data (Jessell et al., 2015) has demonstrated the orientations of mafic dykes that occur in SASCA domain, showed by Papon (1973) on figure 2.

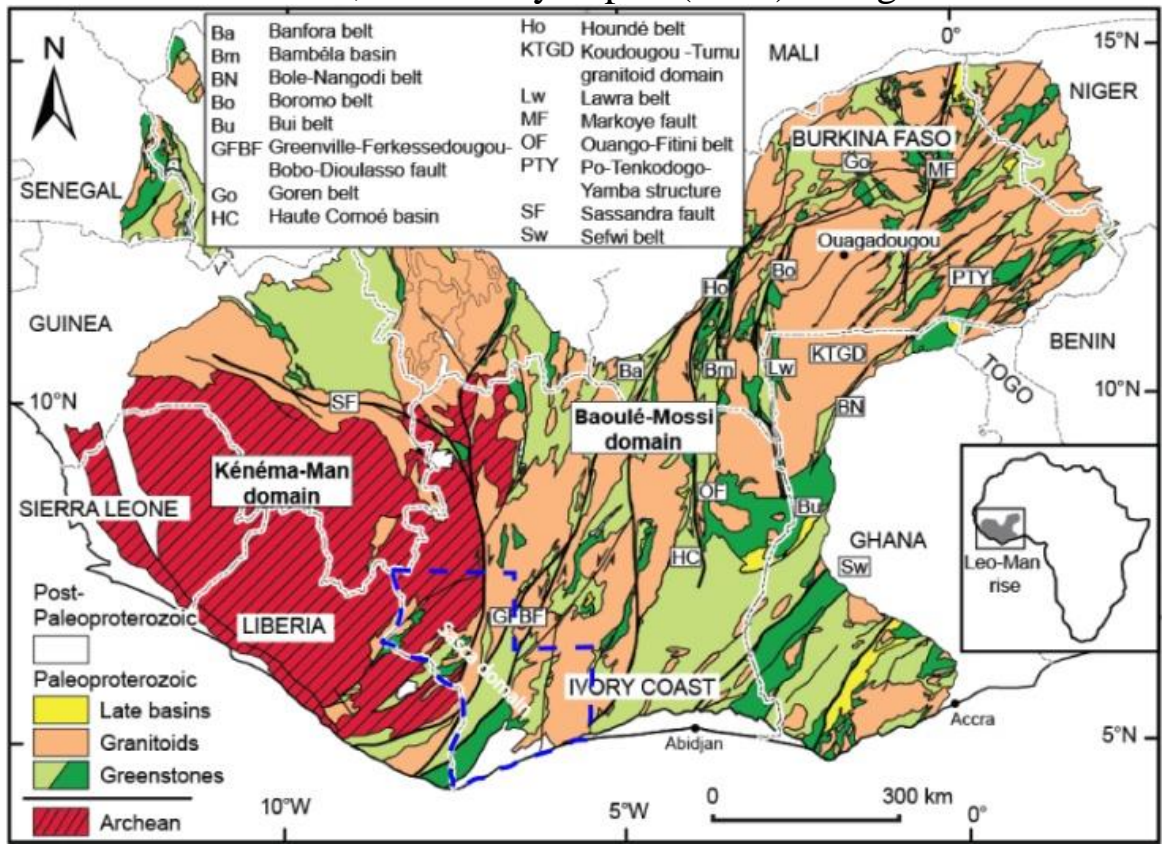

Figure 1. Simplified geological map of the West African Craton, and SASCA Domain, study area. Modified map SIG Afrique by BRGM, Milesi et al.( 2004). 


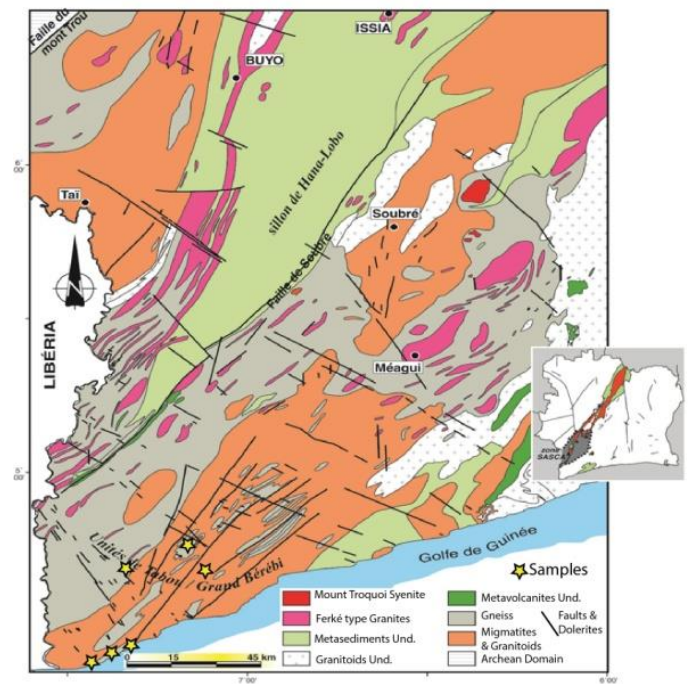

Figure 2. Geological map of the SASCA domain, modified according to Papon (1973) with location of study samples.

This study will focus on the petrographic and geochemical characteristics of metabasites intrusion in the SASCA domain.

\section{Geological Context}

Located in West Africa between longitudes $3^{\circ}$ and $8^{\circ}$ West and latitudes $5^{\circ}$ and $10^{\circ}$ North, Côte d'Ivoire belongs to the West African Craton precisely the Man-Leo Ridge (Bessoles, 1977). It is essentially characterized by a Precambrian age basement and a more recent sedimentary cover. This basement is divided into two main domains: the Kenema-Man domain to the west and the Baoulé-Mossi domain to the east, separated by the transcurrent Sassandra fault. The Kenema-Man domain to the west is largely dominated by Archean terrains. They consist of felsic and mafic gneisses, tonalitestrondhjemites-granodiorites (TTGs) and migmatites associated with narrow greenstone belts of low to high metamorphic grade, supracrustal rocks comprising tholeiitic basalts and metasediments including turbidites, conglomerates and extensive banded iron formations (Camil, 1981, 1984; Kouamelan, 1996; Thieblemont et al., 2004, 2005; Kouamelan et al., 2017). The Baoulé-Mossi domain in the east is defined by juvenile Palaeoproterozoic formations known as Birimian (Junner, 1940). Paleoproterozoic domains lie adjacent to the Archean domain (Figure 1) and are characterized by the typical Archean-like greenstone-granitoid assemblages that principally consist of volcanic, volcano-sedimentary, and sedimentary sequences separated either by extensive TTG and granite provinces or by slightly younger but still Paleoproterozoic sedimentary basins. The Archean and Paleoproterozoic domains were affected by 
multiple tectono- metamorphic and magmatic events, referred to as Leonian (3.2-3.0 Ga); Liberian (2.9-2.7 Ga) and Eburnean (2.15-2.07 Ga) orogenies, (Liégeois et al., 1991, Christian et al., 2004; Thiéblemont, 2005; Gouédji et al., 2014; Kouamelan et al., 2015; Koffi et al., 2020). In particular, the whole complex of volcanic, volcano-sedimentary and sedimentary units has been intruded by several generations of granitoids (Thiéblemont, 2005; Baratoux et al., 2011; Tshibubudze et al., 2013; Kouamelan et al., 2015; Block et al., 2016; Parra-Avila et al., 2017; Kouamelan et al., 2017; Kouadio, 2017). Between the Archean domain and the Paleoproterozoic domain sensu stricto, there is a transition zone limited by the Sassandra fault and the $6^{\circ} \mathrm{W}$ longitude characterized by an Archean heritage materialized by a crustal relic with an age at $3.2 \mathrm{Ga}$ in the south of the SASCA domain (Figure 2; Kouamelan et al., 1997a; Kouamelan et al., 2015). The Mafic intrusive dykes and associated sills crosscut the entire SASCA domain (Papon, 1973; Jessell et al., 2015; Kouadio, 2017). According to Bertrand et al. (2014); Davies et al. (2017) and Marzoli et al. (2018); some dykes in the West African Craton belong to the widely distributed 201 Ma Central Atlantic Magmatic Province (CAMP).

\section{Material and methodology}

A total of 6 metabasite samples were collected in the study area, (Figure 2), (Table 1). Thin sections were made and petrographic determinations were carried out in Abidjan (Félix HOUPHOUËT BOIGNY University) in Côte d'Ivoire and Toulouse (Environmental Geosciences Toulouse, University of Toulouse) in France. Geochemical analyses on total rock were carried out at the Bureau Veritas Mineral Analysis Laboratory in Vancouver, Canada by X-ray fluorescence (XRF) for major elements and by inductively coupled plasma mass spectrometer (ICP MS) for trace elements.

Table 1 : Inventory and coordinates of collected samples

ID. Identifiers, UTM. Universal Transverse Mercator (29N), DMS. Degree minutes

\begin{tabular}{|c|c|c|c|c|c|c|}
\hline & & \multicolumn{5}{|c|}{ Coordinates } \\
\hline & & & Easting- & Northing- & Longitude- & Latitude- \\
\hline ID & Locations & Samples & UTM & UTM & DMS & DMS \\
\hline 1 & Yonaké & CIO2 & $\overline{676597}$ & 486059 & $07^{\circ} 24^{\prime} 30,7^{\prime \prime}$ & $04^{\circ} 23^{\prime} 44,7^{\prime \prime}$ \\
\hline 2 & Boké & CI09 & 678844 & 486135 & $07^{\circ} 23^{\prime} 17,8^{\prime \prime}$ & $04^{\circ} 23^{\prime} 47,0^{\prime \prime}$ \\
\hline 3 & Tabou & CI24 & 682407 & 487752 & $07^{\circ} 21^{\prime} 22,1^{\prime \prime}$ & $04^{\circ} 24^{\prime} 39,4^{\prime \prime}$ \\
\hline 4 & Dehié & CI29 & 683334 & 514412 & $07^{\circ} 20^{\prime} 50,1^{\prime \prime}$ & $04^{\circ} 39^{\prime} 07,2^{\prime \prime}$ \\
\hline 5 & Singhé 1 & $\mathrm{CI} 32$ & 708813 & 509991 & $07^{\circ} 07^{\prime} 03.8^{\prime \prime}$ & $04^{\circ} 36^{\prime} 41,2^{\prime \prime}$ \\
\hline 6 & Baco 1 & CI36 & 703484 & 519487 & $07^{\circ} 09^{\prime} 55.9^{\prime \prime}$ & $04^{\circ} 41^{\prime} 50,8^{\prime \prime}$ \\
\hline
\end{tabular}

\section{Results}

- Petrographic Data 
Metabasites are located along the Atlantic coast and on the continent. They have been identified in several areas of the study area including Yonaké, Boké, Tabou, Dehié, Singhé and Baco1. These formations are few in number and small in extent. These intrusives occur in the form of dykes (dolerites, CI09, CI24) and domes (gabbros, CI02, CI29, CI32, CI36). Their contact with the gneisses is very obvious and have NW-SE trend for the dolerites.

\section{- Dolerites}

Dolerites are very compact melanocratic rocks. They occur in the form of dykes that are crosscutting the host gneissic rocks (Figure 3(a)). They are also strongly magnetized. Most of the dolerites are found on the Atlantic coast, notably in Tabou and Boké. They consist of plagioclase wands visible with a magnifying glass. At the microscopic level, we have a dolerite texture with the following mineralogical composition:

plagioclase : very large abundance of entangled plagioclase wands, one within the other of medium size. These plagioclases have a single macle. The space between the plagioclase wands is occupied by olivine and pyroxene minerals. We notice a beginning of saussuritization of the plagioclases (Figure 3(b, d)),

pyroxene : less abundant than plagioclase. The pyroxenes, especially the augites, have wands-shaped forms with an albite macle and basal sections showing suborthogonal cleavages. The angle of extinction is $\approx 39^{\circ}$, and some sections show the beginning of ouralitization (Figure 3(c, d)),

olivine : a few rare large crystals, subautomorphic with a losangic shape and numerous subparallel breaks. Some sections show the beginning of serpentinization (Figure 3(b)).

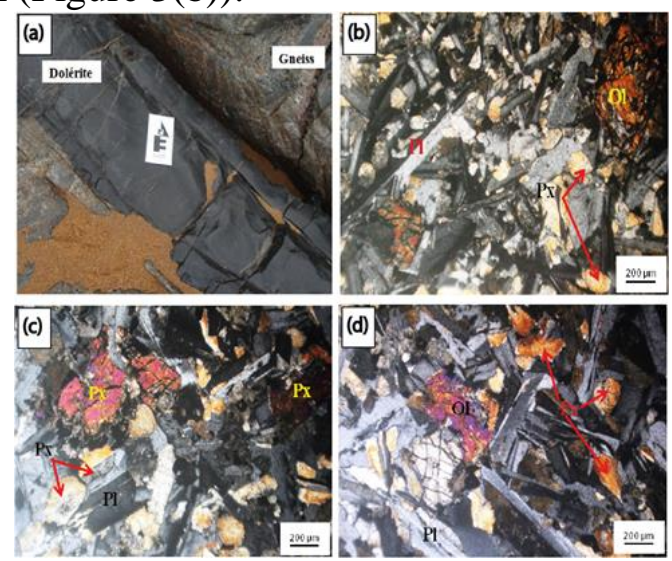

Figure 3. Macroscopic and microscopic aspects of dolerites. (a) Dolerite dyke (N150 $)$ cutting gneiss. (b) Olivine sandwiched between entangled plagioclase wands. (c) Pyroxene minerals having single macles. (d) Plagioclase and pyroxene assembly with pyroxene minerals in the process of ouralitization. $\mathrm{Pl}$ : plagioclase ; $\mathrm{Ol}$ : olivine ; $\mathrm{Px}$ : pyroxene. 


\section{- Gabbros}

Gabbros are medium-grained, grey rocks (Figure 4(a)). These rocks are mostly exposed on the continent, especially at Dehié, Singhé, Yonaké and Bacco 1, and intruded into the gneisses. They are also found not far from the village of Yonaké on the Atlantic coast. Microscopic observation shows a normal grained texture with a slight orientation (granoblastic) and the following mineralogical association:

plagioclase : are generally abundant, occur in two habits: wandsshaped and almond-shaped in inter-crystalline associations (Figure 4(b,d)). They may present both systems of macles (albite and pericline). We observe that plagioclases contain small crystals of embedded biotite. Large patches of plagioclase exist with the presence of clouding marked by saussuritization (primary plagioclase, Figure 4(d)),

pyroxene : abundant in some sections and less in others where we observed a pseudomorphosis into amphibole. Several types of pyroxenes have been described, including the augite with an albite macle (Figure 4(c)). They are in the form of phenocrystals. Some slides show pyroxenes ouralitized and others at the beginning of ouralitization,

green hornblende: Less abundant than plagioclases and pyroxenes, green hornblende is generally xenomorphic to automorphic (Figure 4(e)). In addition to those from pyroxenes, there are primary green hornblendes that destabilize into biotites into the shear corridors. We also observe an onset of chloritization and epidotization of the green hornblends,

biotite : Less abundant than green hornblende, biotite occurs as an elongated wands in the matrix,

quartz : very rare in gabbros and not affected by deformation. It occurs as small crystals (Figure $4(\mathrm{~d}, \mathrm{e})$ ) 


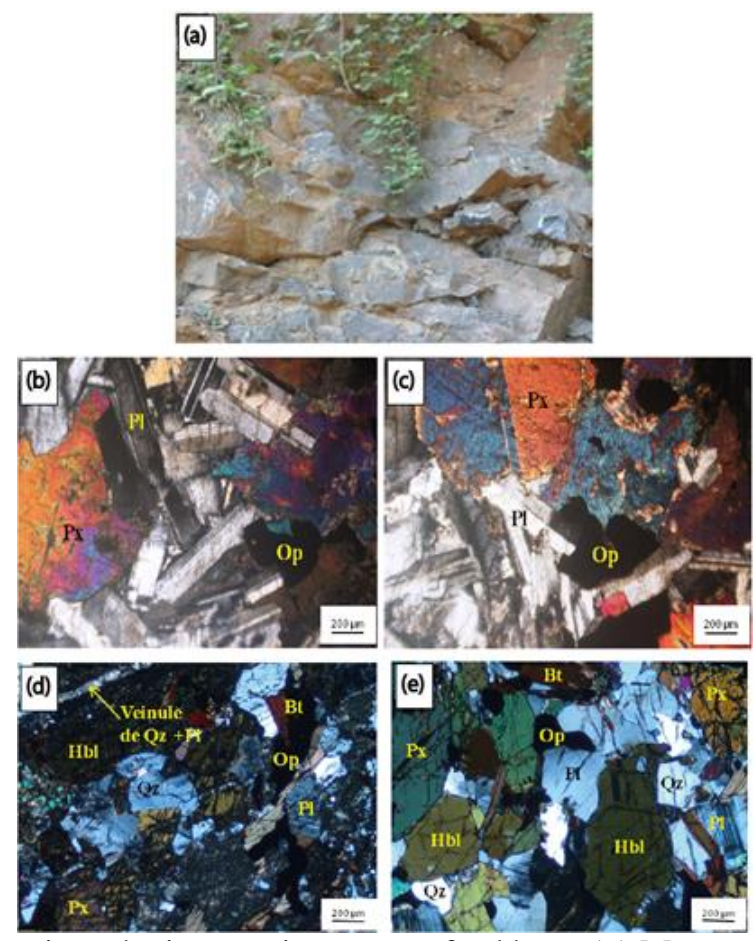

Figure 4. Macroscopic and microscopic aspects of gabbros. (a) Macroscopic appearance of gabbros with a massive and fractured aspect. (b) Entangled plagioclase chopsticks. (c) pyroxene with a single macle. (d) Saussuritization of plagioclase and quartz veinlet. (e) Primary mineralogical gabbro assembly. Pl : plagioclase, Px : pyroxene, $\mathrm{Hbl}$; hornblende, $\mathrm{Bt}$ : biotite, Qz : quartz, Op : opaques.

\section{- Geochemical Data}

This study will make it possible to specify the classification, the geochemical evolution and the geodynamic environment of the metabasites. The chemical composition of the rocks is reported in table 2.

Table 2 : Chemical composition in major elements (\%) and traces elements of metabasites

\begin{tabular}{|c|c|c|c|c|c|c|}
\hline & \multicolumn{2}{|c|}{ Dolerite } & \multicolumn{4}{|c|}{ Gabbro } \\
\hline & CI09 & CI24 & $\overline{\text { CI02 }}$ & CI29 & CI32 & CI36 \\
\hline $\mathrm{SiO2}$ & 49,17 & 50,33 & 50,32 & 49,28 & 46,8 & 50,97 \\
\hline $\mathrm{Al} 2 \mathrm{O3}$ & 14,03 & 13,93 & 18,18 & 13,91 & 13,51 & 15,09 \\
\hline $\mathrm{Fe} 2 \mathrm{O3}$ & 11,88 & 12,85 & 10,34 & 15,35 & 15,76 & 11,91 \\
\hline $\mathrm{FeO}$ & 10,69 & 11,56 & 9,30 & 13,81 & 14,18 & 10,72 \\
\hline $\mathrm{CaO}$ & 8,05 & 9,34 & 9,33 & 8,52 & 7,2 & 9,07 \\
\hline MgO & 8,62 & 8,74 & 4,64 & 4,6 & 6,79 & 6,16 \\
\hline $\mathrm{Na} 2 \mathrm{O}$ & 2,72 & 2,62 & 3,98 & 2,77 & 3,47 & 3,31 \\
\hline K2O & 1 & 0,44 & 0,84 & 1,17 & 1 & 0,7 \\
\hline MnO & 0,15 & 0,17 & 0,15 & 0,2 & 0,33 & 0,16 \\
\hline TiO2 & 1,51 & 1,23 & 1,02 & 3,15 & 1,31 & 1,18 \\
\hline P2O5 & 0,36 & 0,25 & 0,17 & 0,4 & 0,27 & 0,1 \\
\hline $\mathrm{Cr} 2 \mathrm{O3}$ & 0,048 & 0,054 & 0,013 & 0,008 & 0,008 & 0,02 \\
\hline
\end{tabular}




\begin{tabular}{|c|c|c|c|c|c|c|}
\hline $\mathbf{B a}$ & 0,03 & 0,02 & 0,02 & 0,04 & 0,02 & 0,01 \\
\hline LOI & 2,78 & 0,77 & 0,52 & 0,08 & 3,02 & 0,69 \\
\hline SUM & 100,36 & 100,75 & 99,51 & 99,49 & 99,49 & 99,37 \\
\hline $\mathbf{B a}$ & 345 & 222 & 159 & 362 & 171 & 102 \\
\hline Be & $<\mathrm{LD}$ & $<\mathrm{LD}$ & 3 & 5 & $<\mathrm{LD}$ & 2 \\
\hline Co & 49,9 & 49,6 & 36,3 & 43,5 & 59,7 & 38,6 \\
\hline Cs & 0,2 & 0,1 & $<\mathrm{LD}$ & 1,6 & 0,5 & $<\mathrm{LD}$ \\
\hline Ga & 18,9 & 19,9 & 23,2 & 24,7 & 18,7 & 18 \\
\hline Hf & 2,4 & 1,8 & 1,4 & 7,3 & 2,3 & 1,4 \\
\hline $\mathrm{Nb}$ & 14,1 & 5,3 & 5,4 & 24,9 & 7,1 & 5,7 \\
\hline $\mathbf{R b}$ & 14,7 & 8,5 & 13,4 & 30,3 & 18,8 & 8,8 \\
\hline Sn & $<\mathrm{LD}$ & $<\mathrm{LD}$ & $<\mathrm{LD}$ & 2 & 4 & $<\mathrm{LD}$ \\
\hline $\mathrm{Sr}$ & 585,3 & 440,7 & 497,8 & 412,1 & 214,3 & 249 \\
\hline $\mathbf{T a}$ & 0,7 & 0,3 & 1 & 1,5 & 0,3 & 0,6 \\
\hline Th & 0,6 & 0,8 & 0,7 & 3,5 & $<\mathrm{LD}$ & 1,8 \\
\hline $\mathbf{U}$ & $<\mathrm{LD}$ & $<\mathrm{LD}$ & 0,3 & 0,7 & $<\mathrm{LD}$ & 0,9 \\
\hline $\mathbf{V}$ & 146 & 188 & 227 & 348 & 282 & 281 \\
\hline W & $<\mathrm{LD}$ & $<\mathrm{LD}$ & $<\mathrm{LD}$ & $<\mathrm{LD}$ & 1,1 & $<\mathrm{LD}$ \\
\hline $\mathbf{Z r}$ & 95,8 & 64,2 & 59,6 & 273,3 & 81,1 & 49,5 \\
\hline $\mathbf{Y}$ & 14,2 & 17 & 12,9 & 36,5 & 46 & 13,1 \\
\hline La & 14,1 & 12,3 & 10,6 & 30,5 & 7,3 & 4,7 \\
\hline $\mathrm{Ce}$ & 32,2 & 27,7 & 19,5 & 65,6 & 17,9 & 10,1 \\
\hline Pr & 4,47 & 3,73 & 2,61 & 8,64 & 3 & 1,37 \\
\hline Nd & 21,5 & 17,8 & 10,5 & 38,8 & 16,2 & 6 \\
\hline Sm & 4,3 & 3,93 & 2,27 & 8,51 & 4,98 & 1,55 \\
\hline $\mathbf{E u}$ & 1,49 & 1,42 & 1,12 & 2,67 & 1,37 & 0,67 \\
\hline Gd & 4,2 & 4,06 & 2,63 & 8,45 & 6,54 & 1,99 \\
\hline $\mathbf{T b}$ & 0,58 & 0,58 & 0,4 & 1,29 & 1,2 & 0,33 \\
\hline Dy & 3,11 & 3,41 & 2,28 & 7,63 & 8,21 & 2,24 \\
\hline Ho & 0,54 & 0,62 & 0,5 & 1,43 & 1,72 & 0,45 \\
\hline Er & 1,4 & 1,72 & 1,41 & 3,93 & 5,07 & 1,31 \\
\hline Tm & 0,18 & 0,23 & 0,19 & 0,51 & 0,75 & 0,19 \\
\hline $\mathbf{Y b}$ & 1,27 & 1,45 & 1,31 & 3,29 & 5,1 & 1,26 \\
\hline $\mathbf{L u}$ & 0,17 & 0,22 & 0,23 & 0,47 & 0,76 & 0,2 \\
\hline Mo & 0,5 & 0,5 & 0,9 & 0,8 & 0,7 & 0,2 \\
\hline $\mathrm{Cu}$ & 53 & 55,6 & 27,9 & 373,4 & 154,3 & 44,5 \\
\hline $\mathbf{P b}$ & 1,8 & 0,9 & 1,6 & 2,6 & 6,8 & 1,4 \\
\hline Zn & 52 & 33 & 40 & 78 & 195 & 33 \\
\hline $\mathrm{Ni}$ & 149,6 & 117 & 37 & 21,9 & 68,1 & 54,6 \\
\hline $\mathbf{E u} / \mathbf{E u} \mathbf{u}^{*}$ & 1,08 & 1,10 & 1,42 & 0,97 & 0,74 & 1,18 \\
\hline $\mathrm{Ce} / \mathrm{Ce}^{*}$ & 0,95 & 0,96 & 0,87 & 0,95 & 0,90 & 0,94 \\
\hline$(\mathbf{L a} / \mathbf{Y b})_{\mathbf{N}}$ & 7,33 & 5,60 & 5,34 & 6,12 & 0,95 & 2,46 \\
\hline$(\mathbf{L a} / \mathbf{S m})_{\mathbf{N}}$ & 2,00 & 1,91 & 2,85 & 2,18 & 0,89 & 1,85 \\
\hline$(\mathbf{G d} / \mathbf{Y b})_{\mathbf{N}}$ & 2,66 & 2,25 & 1,61 & 2,06 & 1,03 & 1,27 \\
\hline
\end{tabular}

These rocks were described in the petrographic study as dolerites and gabbros. Chemically, the classification diagram of Cox et al, (1979) adapted to plutonic rocks by Wilson, (1989), gives to the metabasites a gabbro composition (Figure 5). The diagram $\left(\mathrm{Na}_{2} \mathrm{O}+\mathrm{K}_{2} \mathrm{O}\right)$ versus $\mathrm{SiO}_{2}$ by 
Middlemost (1994) confirms this gabbroic character of metabasites in the SASCA domain (Figure 6).

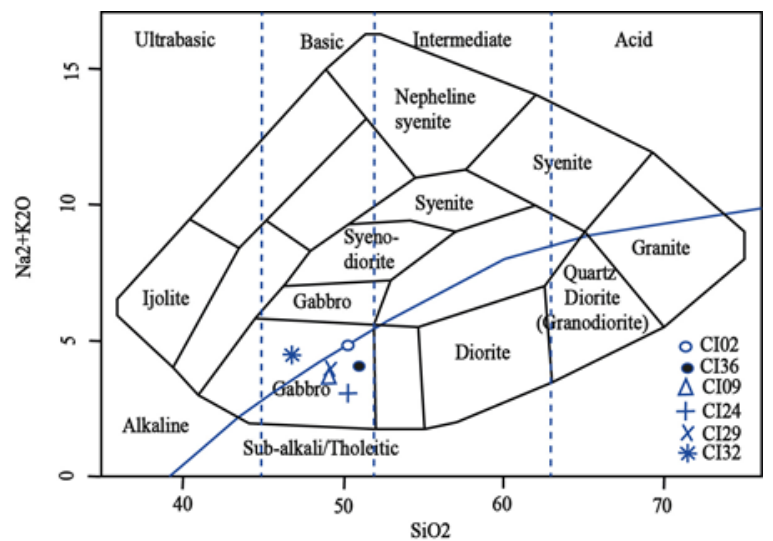

Figure 5. Diagram $\left(\mathrm{Na}_{2} \mathrm{O}+\mathrm{K}_{2} \mathrm{O}\right)$ versus $\mathrm{SiO}_{2}$ (Cox et al., 1979) applied to metabasites.

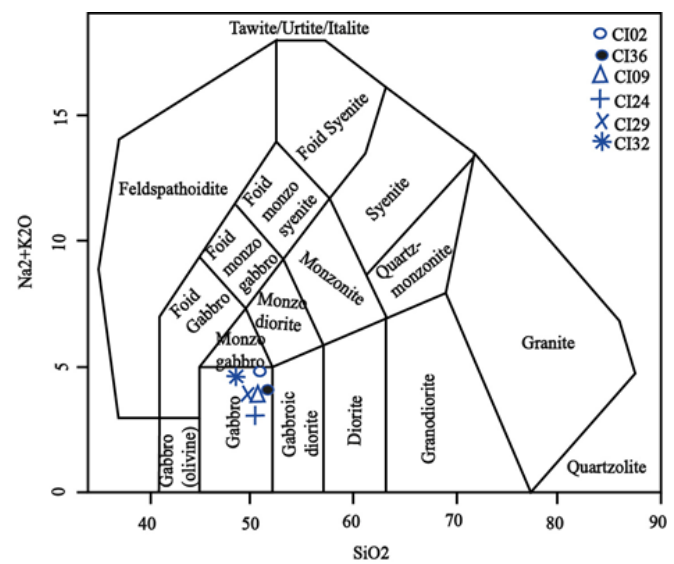

Figure 6. Diagram $\left(\mathrm{Na}_{2} \mathrm{O}+\mathrm{K}_{2} \mathrm{O}\right)$ versus $\mathrm{SiO}_{2}$ from Middlemost (1994) applied to metabasites.

\section{- Composition in major elements}

Metadolerites have $\mathrm{SiO}_{2}$ contents ranging from 49.17 to $50.33 \%$; those of the alkalis $\left(\mathrm{Na}_{2} \mathrm{O}+\mathrm{K}_{2} \mathrm{O}\right)$ vary very slightly from 3.06 to $3.72 \%$. $\mathrm{Al}_{2} \mathrm{O}_{3}$ contents vary from 13.93 to $14.03 \%$; $\mathrm{TiO}_{2}$ contents are low (1.23 to $1.51 \%)$. $\mathrm{MgO}$ contents are between 8.62 and $8.74 \%$. The diagram $\left(\mathrm{Na}_{2} \mathrm{O}+\mathrm{K}_{2} \mathrm{O}\right)$ versus $\mathrm{SiO}_{2}$ by Wilson (1989) gives dolerites subalkaline to tholeiitic characteristics (Figure 5).

Metagabbros have $\mathrm{SiO}_{2}$ concentrations between 46.8 and $50.97 \%$; those of alkalis $\left(\mathrm{Na}_{2} \mathrm{O}+\mathrm{K}_{2} \mathrm{O}\right)$ vary slightly from 3.94 to $4.82 \% . \mathrm{Al}_{2} \mathrm{O}_{3}$ contents vary from 13.51 to $18.18 \%$; those of $\mathrm{TiO}_{2}$ are low (1.02 to $1.18 \%$ ). $\mathrm{MgO}$ contents are between 4.6 and $6.79 \%$. Most of gabbros also belong to 
the subalkaline to tholeiitic series (Figure 5). Only the CI32 sample belongs to an calc-alkaline series.

The ternary AFM diagram proposed by Irvine \& Baragar (1971) to separate the toleiitic series from the calc-alkaline series (Figure 7) proves to be well adapted to the study of metabasite series. The rocks studied show a characteristic evolution of a tholeitic lineage. Gabbros and dolerites are attracted to the iron pole. However, a sample (CI02) of gabbro can be distinguished in the calc-alkaline series field. Reported in the diagram of Miyashiro (1974), all the metabasites are in the tholeite field (Figure 8)

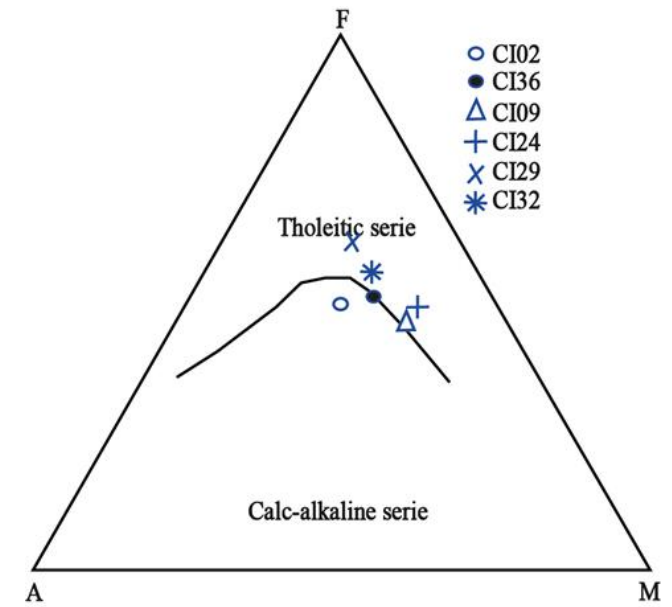

Figure 7. AFM diagram of Irvine and Baragar (1971) applied to metabasites in the SASCA domain. A : $\mathrm{Na}_{2} \mathrm{O}+\mathrm{K}_{2} \mathrm{O} ; \mathrm{F}: \mathrm{FeOt} ; \mathrm{M}: \mathrm{MgO}$.

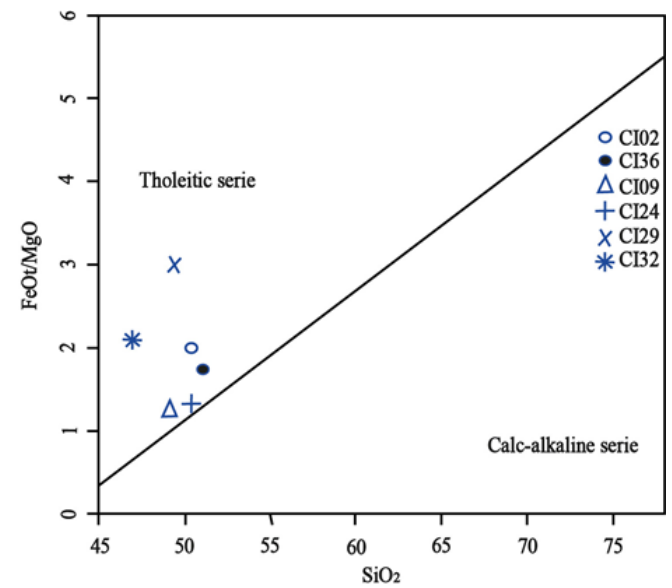

Figure 8. FeOt/MgO vs. $\mathrm{SiO} 2$ diagram (after Miyashiro, 1974]) applied to metabasites in the SASCA domain.

\section{- Trace elements composition}

The metabasites are marked by identical concentrations of cobalt (dolerites: 49.6-49.9 ppm and gabbros: 36.3-59.7 ppm), with differences in 
chromium, vanadium and nickel. The dolerites show: chromium (32.8-36.9 ppm), vanadium (146-188 ppm) and nickel (117-149.6 ppm). Gabbros, on the other hand, are characterized by the following contents: $\mathrm{Cr}$ (8.9-13.7 ppm), V (281-348 ppm) and $\mathrm{Ni}$ (21.9-68.1 ppm). The most magnesian metabasites are dolerites with high levels of $\mathrm{Cr}(36.9 \mathrm{ppm})$ and $\mathrm{Ni}(149.6$ $\mathrm{ppm})$. Radioactive element values are relatively low: $\mathrm{U}(0.3-0.9 \mathrm{ppm})$ and $\mathrm{Th}$ $(0.6-3.6 \mathrm{ppm})$. The zirconium contents are more expressive $(273.3 \mathrm{ppm})$ in the gabbro sample (CI29). The trace elements compositions of metabasites are plotted on multi-element diagrams normalized to the primitive mantle according to the values of Mc Donough (1992), (Figure 9). The profiles are relatively flat with LILE element enrichments ( $\mathrm{Cs}, \mathrm{Rb}, \mathrm{Ba}$ and $\mathrm{K})$ and $\mathrm{Th}$ depletion for the dolerites. There are enrichments in ( $\mathrm{La}, \mathrm{Sr}, \mathrm{P}$ and $\mathrm{Sm}$ ) as well as depletions in HFSE ( $\mathrm{Ta}, \mathrm{Ce}, \mathrm{Nb}, \mathrm{Hf}$ and sometimes $\mathrm{Zr}$ ). There is a positive $\mathrm{U}$ anomaly for all metabasites. The element ratios of the radioactive/radiogenic pairs give $\mathrm{Rb} / \mathrm{Sr}(0.020-0.09)$ very low and $\mathrm{Sm} / \mathrm{Nd}$ high $(0.20-0.31)$ relative to the values $(0.32$ and 0.17 , respectively) estimated by Taylor and McLennan (1985) for the upper continental crust. The observations of positive anomalies in $\mathrm{Rb}, \mathrm{Ba}$ and $\mathrm{K}$ and negative anomalies in $\mathrm{Ta}, \mathrm{Ce}, \mathrm{Nb}$ and sometimes in $\mathrm{Zr}$ allow us to affirm that these rocks would have been contaminated during their emplacement and thus would have formed in a continental context.

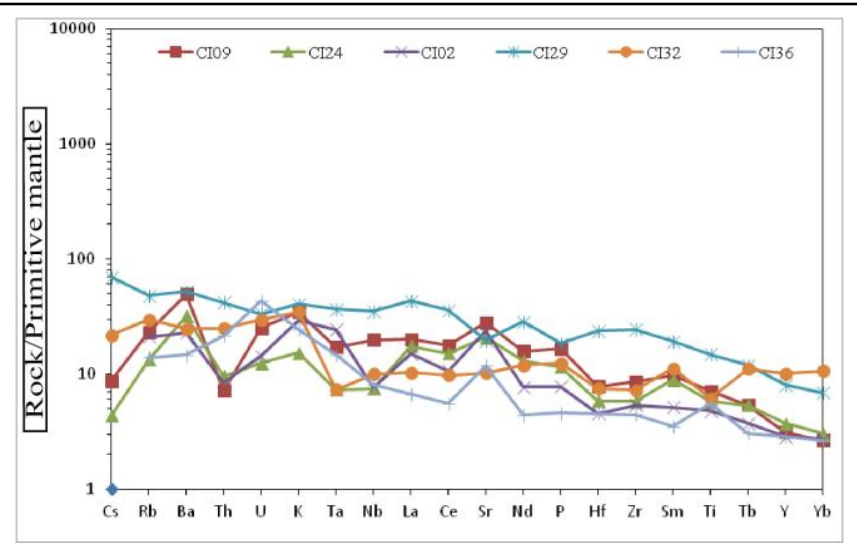

Figure 9. Multi-element spectrum normalized to the primitive mantle applied to metabasites in the SASCA domain.

\section{- Rare earth composition}

Rare earth contents ( $\Sigma$ REE) in dolerites range from 79.17 to 89.51 ppm, while those in gabbros are higher and range from 32.36 to $181.72 \mathrm{ppm}$. The rare earth spectra of metabasites normalized to chondrite values according to Sun and Mc.Donough (1989) are very shallow to flat slopes (Figure 10). Dolerites and gabbros show more or less similar spectra. Their 
fractionation rates are also close and low: dolerites $[(\mathrm{La} / \mathrm{Yb}) \mathrm{N}=5.60$ to 7.33] and gabbros [(La/Yb)N $=0.95$ to 6.12$]$. The dolerites show a slight positive anomaly in europium $\left(\mathrm{Eu} / \mathrm{Eu}^{*}: 1.08-1.10\right)$ same like the gabbros (CI02 and $\mathrm{CI} 36$; Eu/Eu*: 1.18-1.42). This positive anomaly highlights the splitting of the hornblende, which contrary to plagioclase shows little affinity with the europium.

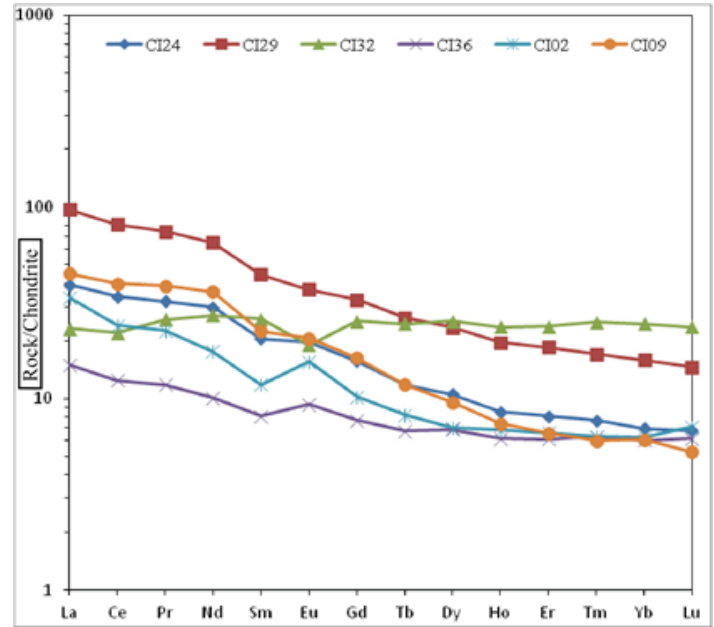

Figure 10. Rare earth spectra of SASCA domain metabasites normalized to chondrite.

The gabbros (CI29 and CI32) show a slight negative europium anomaly $\left(\mathrm{Eu} / \mathrm{Eu}^{*}:\right.$ 0.74-0.97) characteristic of plagioclase splitting. This result was also highlighted in the petrographic study. All the samples show a negative Samarium anomaly except the sample (CI32) which shows a positive Sm anomaly.

\section{- Petrogenesis and geotectonic relationships of metabasites}

Chemical analyses of metabasites in the SASCA domain are projected onto ternary and binary discriminant diagrams to establish petrogenetic and geotectonic relationships. Gabbros and dolerites are projected in the $(\mathrm{Th} / \mathrm{Yb})$ versus $(\mathrm{Nb} / \mathrm{Yb})$ diagram of Pearce et al. 2008, (Figure 11). These metabasites show geochemical signatures close to EMORB and OIB type basalts. The diagram $(\mathrm{Th} / \mathrm{Yb})$ versus $(\mathrm{Nb} / \mathrm{Yb})$, also shows that metabasites in the SASCA domain are marked by high $\mathrm{Nb} / \mathrm{Yb}$ ratios (1.39-11.10). Their low $\mathrm{Th} / \mathrm{Yb}$ values $(0.47-1.43)$ are indicative of subduction or crustal contamination. 


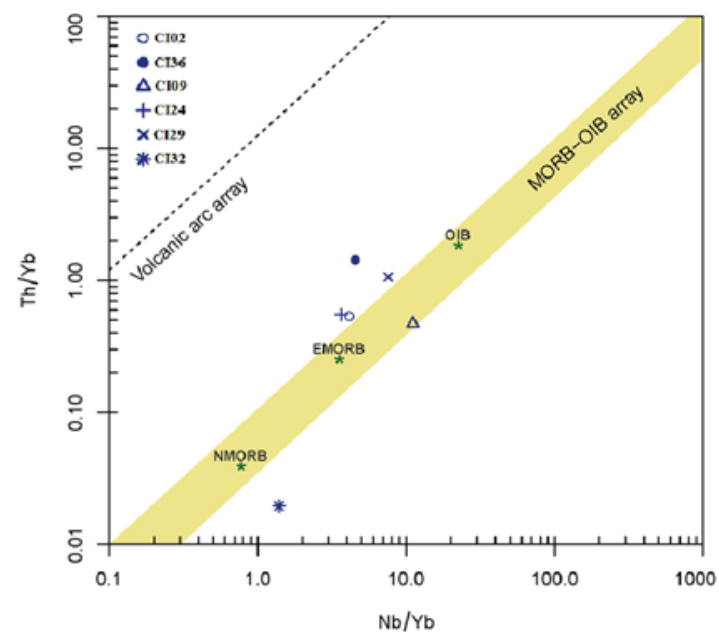

Figure 11. Diagram $(\mathrm{Th} / \mathrm{Yb})$ versus $(\mathrm{Nb} / \mathrm{Yb})$ from Pearce (2008) applied to SASCA domain metabasites. NMORB: N-type mid-oceanic ridge basalt; EMORB: E-type mid-oceanic ridge basalt; OIB: oceanic island basalt

These rocks are marked by enrichment in large lithophilic ions (LILEs) and considerable depletion in high potential elements (HFSE) (Nb, $\mathrm{Ta}, \mathrm{Ce}, \mathrm{Hf}$ and $\mathrm{Zr}$; Figure 9)

The diagram $\left(\mathrm{TiO}_{2} / \mathrm{Yb}\right)$ versus $(\mathrm{Nb} / \mathrm{Yb})$ from Pearce et al. 2008 (Figure 12) confirms the affinity of SASCA domain metabasites for EMORB-OIB basalts and suggests a depleted magmatic source, intermediate between E-MORB and OIB. This diagram also highlights the tholeiitic character of the rocks studied. However, a sample of gabbros (CI32) stands out and falls within the field of N-MORB type basalts. Furthermore, with the exception of the CI32 sample, the metabasites are found in the field of intraplate basalts (Pearce and Cann, 1973) (Figure 13).

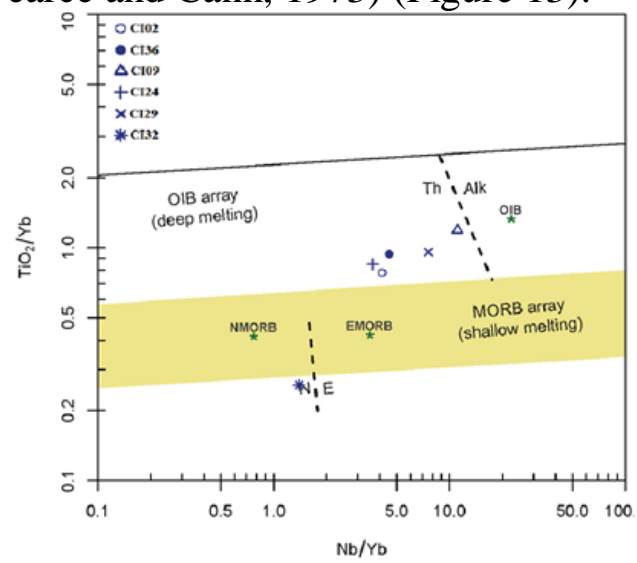

Figure 12. Diagram $\left(\mathrm{TiO}_{2} / \mathrm{Yb}\right)$ versus $(\mathrm{Nb} / \mathrm{Yb})$ from Pearce (2008) applied to metabasites in the SASCA domain. NMORB: N-type mid-oceanic ridge basalt; EMORB: E-type midoceanic ridge basalt; OIB: oceanic island basalt; Th: tholeitic; Alk: alkaline 


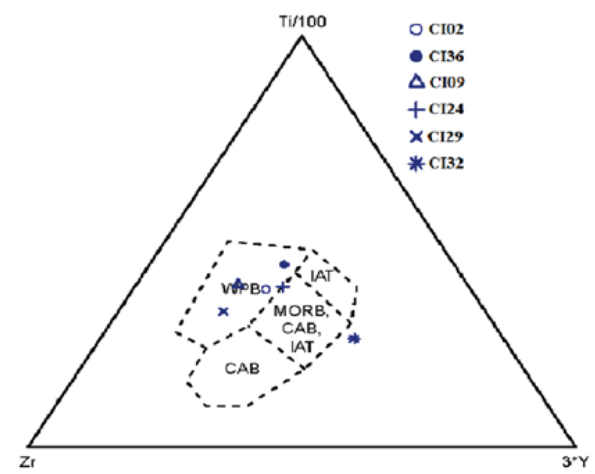

Figure 13. Ti/100-Zr-Yx3 diagram by Pearce and Cann (1973) applied to metabasites in the SASCA domain. WPB: intraplate basalts; IAT: island arc tholeiiites; CAB: calc-alkaline basalts; MORB: mid-oceanic ridge basalt.

\section{Discussion}

The metabasites consist of granoblastic-textured gabbro and doleritictextured dolerite dyke. The SASCA domain dolerites are NW-SE oriented like those of Papon (1973) in the SASCA domain; Bogdanova et al (2013) in the Ukrainian Shield of Volgo-Sarmatina and Jessell et al (2015) in the West African Craton (WAC). These formations resemble mineralogically (Plagioclase, Pyroxene, Olivine, Green Hornblende, Biotite, rare Quartz) and structurally (NW-SE direction) to the metabasites of the Reguibat Ridge in Mauritania (Hamoud et al., 2015); Burkina Faso (Wenmenga et al., 2009; Baratoux et al., 2019). The metabasites of the SASCA domain thus originate from the Central Atlantic magmatic Province (CAMP), which represents one of the largest basalt floodplain regions ever, and is linked to the opening of the Atlantic Ocean during the Triassic-Jurassic transition about $200 \mathrm{Ma}$ ago (Kio-A-Sen, 2010; Baratoux et al., 2019). Outside the SASCA domain, metabasites are rather consistent with geological formations (NE-SW trending Sills, Houssou, 2013, Baratoux et al., 2019).

Geochemical data, especially the major elements, have discriminated metabasites as gabbros (Cox et al., 1979; Middlemost, 1994). These rocks are rich in $\mathrm{SiO}_{2}$ and poor in $\mathrm{K}_{2} \mathrm{O}$ and $\mathrm{Na}_{2} \mathrm{O}$ and belong to a tholeiitic series, including those of South America (Kio-A-Sen, 2010). These data are reliable, because the metabasites have retained their original composition of immobile elements since they have not undergone fusion, therefore no extraction of magma (Vigneresse et al., 1996; Vigneresse, 2007; Montreuil and Constantin, 2010). These metabasites show geochemical signatures close to E-MORB and OIB type basalts. The diagram $(\mathrm{Th} / \mathrm{Yb})$ versus $(\mathrm{Nb} / \mathrm{Yb})$ also shows that metabasites of the SASCA domain are marked by high $\mathrm{Nb} / \mathrm{Yb}$ ratios (1.39-11.10). Their low $\mathrm{Th} / \mathrm{Yb}$ values (0.47-1.43) are indicative of subduction or crustal contamination. Trace elements show a clear depletion in HFSE ( $\mathrm{Nb}, \mathrm{Ta}, \mathrm{Zr}, \mathrm{Hf}, \mathrm{Ce}$ ) below the values of the Primitive mantle is 
systematic. The main rare earth element signature is an enrichment in LREE [( $\mathrm{La} / \mathrm{Sm}) \mathrm{N}=0.89$ to 2.85]. There is also a marked enrichment in Sr. These characteristics also indicate those of a magmatic arc source associated with subduction (Wenmenga et al., 2009; Capdevila, 2010; Lamirande and Bilodeau, 2018). The metabasites studied are more enriched in LILE (Sr, K, $\mathrm{Rb}$ and $\mathrm{Ba}$ ). This enrichment is similar to young volcanic arc basalts from Penguin Island (Shetland South) and Grenada (Lesser Antilles; Pearce, 1982; Weaver, 1980). These geochemical characters are different from those described respectively by Daouda (1998), Houssou (2013) and Gnanzou (2014) in the basalts of the Toumodi region, the Agbahou deposit in the Fettêkro belt and the basalts of the volcanosedimentary belt of the Dabakala region. These metabasites were hosted in an intraplate basalt or volcanic arc basalt environment and show a positive and negative $\mathrm{Eu}$ anomaly. This positive and negative anomaly trend is probably due to a divergence in the magmatic evolution of these rocks. The metabasites of the SASCA domain, compared to the basalts of the Toumodi region, the basalts of the Agbahou deposit and those of the volcano-sedimentary series of the Dabakala region show similarities and differences. The metabasites of the different areas mentioned all belong to a tholeiitic series (Figure 14). However, there is a difference in the composition of the source of the metabasites. The metabasites of the SASCA domain show, in fact, a source composition between E-MORB and OIB (Figure 15). Whereas the basalts of the Toumodi area, Fettêkro belt and Dabakala area all have an N-MORB type composition (Figure 15).

The signature of the mafic rocks, however, indicates that a subduction process was indeed active at the continental margin of southwest Côte d'Ivoire and hence the SASCA domain (Kouadio et al., 2016; Koffi et al., 2018).

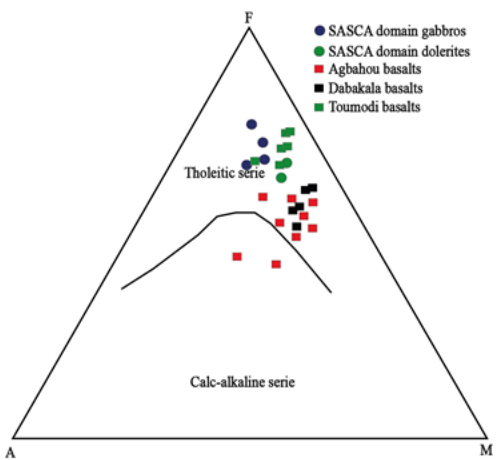

Figure 14. AFM diagram of Irvine and Baragar (1971), applied to metabasites of the SASCA domain, basalts of the Toumodi region, basalts of the Agbahou deposit in the Fettekro belt and basalts of the volcano-sedimentary series of the Dabakala region. A : $\mathrm{Na}_{2} \mathrm{O}+\mathrm{K}_{2} \mathrm{O} ; \mathrm{F}$ : FeOt; M: MgO. 


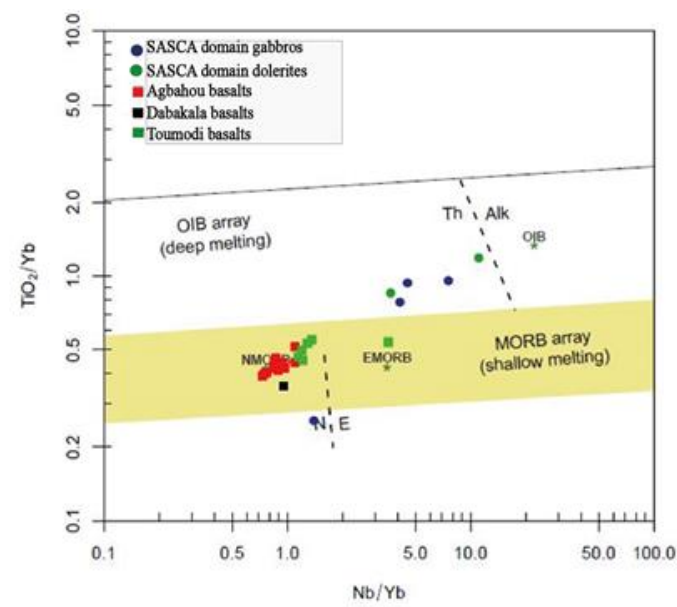

Figure 15. Diagram $\left(\mathrm{TiO}_{2} / \mathrm{Yb}\right)$ versus $(\mathrm{Nb} / \mathrm{Yb})$ from Pearce (2008), applied to SASCA domain metabasites, basalts in the Toumodi region, basalts in the Agbahou deposit in the

Fettêkro belt and basalts of the volcano-sedimentary series in the Dabakala region. NMORB : N-type mid-oceanic ridge basalt; EMORB : E type mid-oceanic ridge basalt ;

OIB : ocean island basalt; Th : tholeitic ; Alk : alkaline

\section{Conclusion}

At the end of this study it should be noted that metabasites are composed of dolerites and gabbros. These rocks are discordant to the gneisses and of low extent and often present oriented minerals. From the petrographic point of view their texture is granoblastic for gabbros and doleritic for dolerites. The mineralogical assemblage of the dolerites consists mainly of plagioclase wands, olivines and pyroxenes. The mineralogical assemblage of gabbros consists of pyroxene, plagioclase, green hornblende, biotite and rare quartz. The geochemical study of the metabasites allows us to know that the most of the analyzed rocks belong to a tholeiitic series and were set up in the field of intraplate basalts or volcanic arc basalt. This result is corroborated by the positive anomalies in $\mathrm{Rb}, \mathrm{Ba}$ and $\mathrm{K}$ as well as the negative anomalies in $\mathrm{Ta}, \mathrm{Ce}, \mathrm{Hf}, \mathrm{Nb}$ and $\mathrm{Zr}$, allowing us to affirm that these rocks would have been contaminated during their emplacement in a subduction context and thus would be formed in a continental context. Finally, the metabasites show a considerable depletion in high potential elements (HFSE) ( $\mathrm{Nb}, \mathrm{Ta}, \mathrm{Ce}, \mathrm{Hf}$ and $\mathrm{Zr}$ ), low in heavy rare earths (HREE) and positive and negative anomalies in europium.

\section{References:}

1. Baratoux, L., Metelka, V., Naba, S., Jessell, M.W., Grégoire, M., Ganne, J., (2011). Juvenile Paleoproterozoic crust evolution during the Eburnean orogeny (2.2-2.0 Ga), western Burkina Faso. Precambrian Research, 191, 18-45. 
https://doi.org/10.1016/j.precamres.2011.08.010

2. Baratoux L., Söderlund U., Ernst R. E., De Roever E., Jessell M. W., Kamo S., Naba S., Perrouty S., Metelka V., Yatte D., Grenholm M., Diallo D. P., Ndiaye P. M., Dioh E., Cournède C., Benoit M., Baratoux D., Youbi N., Rousse S. and Bendaoud A. (2019). New U$\mathrm{Pb}$ Baddeleyite Ages of Mafic Dyke Swarms of the West African and Amazonian Cratons: Implication for Their Configuration in Supercontinents Through Time. Springer Nature Singapore Pte Ltd. (2019). https://doi.org/10.1007/978-981-13-1666-1_7

3. Bessoles B., (1977). Geology of Africa, 1. The West African Craton. Paris, Mém. B.R.G.M., France, n ${ }^{\circ} 88,404$ p.

4. Bertrand H., Fornari M., Marzoli A., García-Duarte R., and Sempere T. (2014). The Central Atlantic Magmatic Province extends into Bolivia. Lithos, 188. 33-43. https://doi.org/10.1016/j.lithos.2013.10.019

5. Block S., Baratoux L., Zeh A., Laurent O., Brugier O., Jessell M., Ailleres L., Sagna R., Parra-Avila L. A., Bosch D. (2016). Paleoproterozoic juvenile crust formation and stabilisation in the south-eastern West African Craton (Ghana); New insights from U$\mathrm{Pb}-\mathrm{Hf}$ zircon data and geochemistry. Precambr Res, 287. 1-30. https://doi.org/10.1016/j.precamres.2016.10.011

6. Bogdanova S .V., Gintov O. B., Kurlovich D. M., Lubnina N. N., and Nilsson M. K. M., (2013). Late Palaeoproterozoic mafic dyking in the Ukrainian Shield of Volgo-Sarmatia caused by rotation during the assembly of supercontinent Columbia (Nuna). Lithos, 174. 196-216. DOI: 10.1016/j.lithos.2012.11.002

7. Camil J., (1981). An example of prograde metamorphism from the base of the amphibolite facies to the granulite facies in the Man region (western Côte d'Ivoire). C. R. Acad. Sci. Paris, 293: 513-518.

8. Camil J., (1984). Petrography, chronology of the archaeological ensembles and associated formations in the Man region (Côte d'Ivoire). Implications for the geological history of the West African craton. Doctoral thesis ès Sci. Univ. d'Abidjan, Côte d'Ivoire, 306 p.

9. Capdevila R., (2010). Les granites varisques du Massif Armoricain. Bulletin de la Société Géologique et Minéralogique de Bretagne, Société géologique et minéralogique de Bretagne, 2010, Série D (7), 1-52.

10. Cox K. G., Bell J. D. and Pankhurst R. J., (1979). The interpretation of igneous rocks. George, Allen and Unwin, London. 401 p.

11. Daouda Y. B., (1998). Lithostratigraphie et pétrologie des formations birimiennes de Toumodi-Fettêkro (Côte d'Ivoire). Implication pour 
l'évolution crustale du paléoprotérozoïque du craton-africain. Thèse de Doctorat, Universté d'Orléans. Mémoire BRGM nº737, 191 p.

12. Davies J.H.F.L, Marzoli A., Bertrand H., Youbi N., Ernesto M. and Schaltegger U. (2017). End-Triassic mass extinction started by intrusive CAMP activity. Nat Commun.

https://doi.org/10.1038/ncomms15596

13. De Roever, E., Lafon, J., Delor, C., Cocherie, A., Rossi, P., Guerrot, C. and Potrel, A., (2003). The Bakhuis ultrahigh-temperature granulite belt (Suriname); 1. Petrological and geochronological evidence for a counterclock wise P-T path at 2.07-2.05 GA. Géologie de la France, 2-3-4. 175-205.Google Scholar

14. El Bahat A., Ikenne M., Söderlund U., Cousens B., Youbi N., Ernst R., Soulaimani A., El Janati M., and Hafid A. (2013) U-Pb ages and geochemistry of dolerite dykes in the Bas Drâa Inlier of the AntiAtlas of Morocco: newly identified $1380 \mathrm{Ma}$ event in the West African Craton. Lithos 174:85-98. https://doi.org/10.1016/j.lithos.2012.07.022

15. Ernst R., E. (2014) Large Igneous Provinces. Cambridge University Press, $653 \mathrm{p}$.

16. Gnanzou A., (2014). Etude des séries volcano-sédimentaires de la région de Dabakala (Nord-Est de la Côte d'Ivoire): genèse et évolution magmatique. Contribution à la connaissance de la minéralisation aurifère de Bobosso dans la série de la Haute-Comoé. Thèse de Doctorat, Univ. Paris-Sud Orsay, France et Univ.Félix Houphouët-Boigny, 303 p.

17. Gouédji, F., Picard, C., Coulibaly, Y., Audet, M. A., Auge, T., Goncalves, P., Paquette, J.- L. and Ouattara, N., (2014). The samapleu mafic and ultramafic intrusion and its Ni-Cu-PGE mineralization: an Eburnean $(2.09 \mathrm{Ga})$ feeder dyke to the Yacouba layered complex (Man Archean craton, western Ivory Coast). Bull. Soc. Geol. Fr. 185, 393-411.

18. Hamoud A., EL Hadi, H., Chakiri S., and Tahiri A. (2015). Caractérisation Pétrographique et Géochimique des Métabasites Archéennes d'Amsaga Est (Dorsale de Reguibat, Mauritanie). European Journal of Scientific Research. 135. 228-242.

19. Houssou N. N., (2013). Étude pétrologique, structurale et métallogénique du gisement d'or d'Agbahou, Divo, Côte d'Ivoire. Thèse de doctorat, Université Félix Houphouët-Boigny. 176 p.

20. Irvine T. N., and Baragar W. R. A., (1971). A guide to the chemical classification of the common volcanic rocks: Canadian Journal of Earth Sciences, v. 8. 523-548. 
21. Jessell M.,W., Santoul J., Baratoux L., Youbi N., Ernst R., E., Metelka V. and Perrouty P. (2015). An updated map of West African mafic dykes. J Afr Earth Sci 112(B). 440-450.

https://doi.org/10.1016/j.jafrearsci.2015.01.007

22. Junner, N. R., (1940). Geology of the Gold Coast and Western Togoland, with revised geological map. Gold Coast Geol. Surv., Bull. $\mathrm{n}^{\circ} 11,40 \mathrm{p}$.

23. Kioe-A-Sen, N., M., E (2010). Petrogenesis of dolerites from Suriname, Ivory Coast and Burkina Faso. A magmatic connection between South America and West Africa preceding the initial opening of the Central Atlantic Ocean. Utrecht University Repository Faculty of Geosciences Theses. https://dspace.library.uu.nl/handle/1874/179622

24. Koffi G. R.-S, Kouamelan A. N., Allialy M. E., Coulibaly Y., Peucat J.-J. (2020). Re-evaluation of Leonian and Liberian events in the geodynamical evolution of the Man-Leo Shield (West African Craton), Precambrian Research. doi:

https://doi.org/10.1016/j.precamres.2019.105582

25. Koffi, Y. A., Kouamelan, A. N., Djro, S. C., Kouadio, F. J.-L. H., Teha, K. R., Kouassi, B. R., and Koffi, G. R. S. (2018). Petrography and Origin of the Metasediments of SASCA Domain (SW of Côte d'Ivoire). In ternational Journal of Innovation and Applied Studies, 23, 451-464. http://www.ijias.issr-journals.org

26. Kouadio F.J.L.H. (2017). Étude pétrostructurale des formations géologiques du sud-ouest de la Côte d'Ivoire (secteur Bliéron Grand-Béréby) : apport de la géochimie et du couple déformationmétamorphisme. Thèse unique. Université Félix Houphouët-Boigny de Cocody. 220 p.

27. Kouadio, F. J.-L. H., Djro, S. C., Kouamelan, A. N., Allialy, M. E., and Koffi, Y. A. (2016). Petrographic and Geochemical Signatures of the Paragneisses of the Tabou and Grand- Béréby Sectors (SouthWestern Côte d'Ivoire). International Journal of Innovation and Applied Studies , 18, 646-658. http://www.ijias.issr-journals.org

28. Kouamélan A.N. (1996). Géochronologie et géochimie des formations archéennes et protérozoïques de la dorsale de Man en Côte d'Ivoire, implication pour la transition archéen-protérozoïque. Thèse de Doctorat Université de Rennes1, France, $\mathrm{n}^{0} 73,290 \mathrm{p}$.

29. Kouamelan, A.N., Djro S.C., Allialy, M.E., Piquette J-L., Peucat J-J., (2015). The oldest rock of Ivory Coast, Journal of African Earth Sciences 103, 65-70. https://doi.org/10.1016/j.jafrearsci.2014.12.004 
30. Kouamelan, A. N., Peucat, J. J. et Delor, C., (1997a). Reliques archéennes $(3.15 \mathrm{Ga})$ au sein du magmatisme Birimien $(2.1 \mathrm{Ga}) \mathrm{de}$ Côte d'Ivoire, Craton Ouest-Africain. C.R. Acad. Sci. 324, 719-727.

31. Kouamelan, A. N., Kra K. S. A., Djro S. C., Paquette J. L. and Peucat J. J., (2017). The Logouale Band: A large Archean crustal block in the Kenema-Man domain (Man-Leo rise, West African Craton) remobilized during Eburnean orogeny (2.05 Ga), Journal of African Earth Sciences. Vol. 148, 6-13.

https://doi.org/10.1016/j.jafrearsci.2017.09.004

32. Kouyaté D., Söderlund U., Youbi N., Ernst R., Hafid A., Ikenne M., Soulaimani A., Bertrand H., Janati M. and Chaham K., R. (2013). U$\mathrm{Pb}$ baddeleyite and zircon ages of $2040 \mathrm{Ma}, 1650 \mathrm{Ma}$ and $885 \mathrm{Ma}$ on dolerites in the West African Craton (Anti-Atlas inliers): Possible links to break-up of Precambrian supercontinents. Lithos 174. 71-84. https://doi.org/10.1016/j.lithos.2012.04.028

33. Lamirande P.-H. et Bilodeau C. (2018). Géochimie et pétrogenèse des métabasites du Complexe de Kaslac, Nunavik, Québec. Energie et Ressources naturelles. MB 2018-15.

34. Liégeois, J.-P., Claessens, W., Camara, D., and Klerkx, J., (1991). Short-lived eburnian orogeny in southern Mali: geology, tectonics, U$\mathrm{Pb}$ and $\mathrm{Rb}-\mathrm{Sr}$ geochronology. Precambrian Research, 50(1):111-136. https://doi.org/10.1016/0301-9268(91)90050-K

35. Martin, H., Moyen, J.-F., Guitreau, M., Blichert-Toft, J., Le Pennec, J.-L. (2014). Why Archaean TTG cannot be generated by MORB melting in subduction zones. Lithos, 198-199, 1-13. https://doi:10.1016/j.lithos.2014.02.017

36. Marzoli A, Callegaro S, Dal Corso J, Davies JHFL, Chiaradia M, Youbi N, Bertrand H, Reisberg L, Merle R, Jourdan F., (2018). The Central Atlantic Magmatic Provinces (CAMP): a review. In: Tanner LH (ed) The late triassic world, topics in geobiology, vol 46, Springer, Berlin, 91-125.

37. Mc Donough W. F., (1992). Using geochemical data: evaluation, presentation, interpretation. Mém. BRGM, Paris, n40, 143 p.

38. Middlemost E., (1994). Magmas, Rocks and Planetary Development. Longman, Harlow, 299 p.

39. Milesi J. P., Feybesse, J. L., Pinna, P., Deschamps, Y., Kampunzu, H., Muhongo, S., Lescuyer, J. L., Le Goff, E., Delor, C., Billa, M., Ralay, F. and Heinry, C., (2004). Geological map of Africa 1:10,000,000, SIG Afrique project. In: 20th Conference of African Geology, BRGM, Orleans, France, 2-7 June.

40. Miyashiro A., (1974). Volcanic rock series in island arcs and active continental margins: American Journal of Science, v. 274, 321-355. 
41. Montreuil, J.-F., and Constantin, M., (2010). The geochemistry of mafic gneisses from the Renzy terrane, western Grenville Province, Quebec: Implications for the geodynamic setting of the early Mesoproterozoic Laurentian margin: Precambrian Research, v. 181, no. 1, 150-166. https://doi.org/10.1016/j.precamres.2010.06.001

42. Moorbath, S., (1975). Evolution of Precambrian crust from strontium isotopic evidence. Nature 254, 395-398.

43. Moorbath, S., O'Nions, R.K., Pankhurst, R.J., Gale, N.H., McGregor, V.R., (1972). Further rubidium-strontium age determinations on the very early Precambrian rocks of Godthaab region, West Greenland. Nature 240, 78-82.

44. Nomade S., Chen Y., Pouclet A., Féraud G., Théveniaut H., Daouda B., Y., Vidal M. and Rigolet C., (2003). The Guiana and WestAfrican Shield Paleoproterozoic grouping: new paleomagnetic data for French Guiana and Ivory Coast. GeophysJInt 154:677-694. Geophysical Journal International, Volume 154, Issue 3, September 2003, 677-694, https://doi.org/10.1046/j.1365-246X.2003.01972.x

45. Papon A., (1973). Geology and Mineralization of Southwestern Côte d'Ivoire. Memory of the BRGM, Paris, No. 80, 284 p.

46. Parra-Avila L.A., Kemp A.I., Fiorentini M.L., Belousova E., Baratoux L., Block S., Jessell M., Bruguier O., Begg G.C., Miller J., Davis J., McCuaig T., C., (2017). The geochronological evolution of the Paleoproterozoic Baoulé-Mossi domain of the Southern West African Craton. Precambrian Research. 300, 1-27. https://doi.org/10.1016/j.precamres.2017.07.036

47. Pearce J.A., (1982). The role of sub-continental lithosphere in magma genesis at active continental margins. In: C.J. Hawkeswoth \& M.J. Norry (Editors). Continental basalts and mantle xenoliths, Shiva Geology Series, 230-240.

48. Pearce J. A., (2008). Geochemical fingerprinting of oceanic basalts with applications to ophiolite classification and the search for Archean oceanic crust: Lithos, v. 100, 14-48.

49. Pearce J. A. and Cann J. R., (1973). Tectonic setting of basic volcanic rocks determined using trace element analyses. Earth Planet. Sci. Lett. 19: 290-300.

50. Savanier, D., Guille, G., Maury, R.C., Blais, S., Guillou, H., Legendre, C., Rossi, P., (2003). Geology, petrology and radiochronology of Nuku Hiva (Marquesas Island, French Polynesia). EGS-AGU-EUG Joint Assembly, Nice, France, 6-11, April 2003, Abstract id. 1105. 
51. Sun S. S. and Mc Donough W. F., (1989). Chemical and isotopic systematics of oceanic basalts: implications for mantle composition and processes. Geological Society Special Publication, 42, 313-345.

52. Taylor S.R. and Mc Lennan S.M., (1985). The continental crust: its composition and evolution. Blackwell, Oxford, $312 \mathrm{p}$.

53. Thiéblemont, Denis. (2005). Geology and petrology of Archean rocks in Guinea: a regional contribution to the knowledge of continental crust formation. Thesis, University of Western Bretagne - Brest, 2005. $149 \mathrm{p}$.

54. Thiéblemont D., Goujou J. C., Egal E., Cocherie. A., Delor. C., Lafon J. M. and Fanning. C. M., (2004). Archaean evolution of the Leo Rise and its Eburnean reworking. Journal of African Earth Sciences. Vol. 39. 97-104. https://doi.org/10.1016/j.jafrearsci.2004.07.059

55. Tshibubudze A, Hein K., A., A., (2013). Structural setting of gold deposits in the Oudalan-Gorouol volcano-sedimentary belt east of the Markoye Shear Zone, West African Craton. J Arf Earth Sci 80:3147. https://doi.org/10.1016/j.jafrearsci.2012.11.010

56. Vigneresse, J.-L., (2007). The role of discontinuous magma inputs in felsic magma and ore generation: Ore Geology Reviews, v. 30, no. 3, 181-216. https://doi.org/10.1016/j.oregeorev.2006.03.001

57. Vigneresse, J. L., Barbey, P. and Cuney, M., (1996). Rheological transitions during partial melting and crystallization with application to felsic magma segregation and transfer: Journal of Petrology, v. 37, no. 6, 1579-1600. https://doi: 10.1093/petrology/37.6.1579

58. Weaver B. L., (1980). Rare-Earth Element geochemistry of Madras granulites. Contrib. Mineral. Petrol., 71: 271-279.

59. Wenmenga U., Kecir M., Tapsoba B. and Lo C-H. (2009). Magmatic Affinity and Geotectonic Setting of Post-Birimian Doleritic Dyke of Boussouma area (Burkina Faso, West- African Craton). Egyptian Journal of Geology, v.53, 2009, 101-114. https://www.researchgate.net/publication/280317910

60. Wilson M., (1989). Igneous Petrogenesis. A Global Tectonic Approach. $\mathrm{xx}+466$ p. London: Unwin Hyman.

61. Youbi N., Kouyaté D., Söderlund U., Ernst R. E., Soulaimani A., Hafid A., Ikenne M., Bahat A. E., Bertrand H., Chaham K. R., Abbou M. B., Mortaji A., Ghorfi M. E., Zouhair M., M E. Janati.M E. (2013). The 1750 Ma Magmatic Event of the West African Craton (Anti-Atlas, Morocco). Precambr Res 236. 106-123.

https://doi.org/10.1016/j.precamres.2013.07.003 